\title{
The influence of learning media and learning interests on student learning outcomes
}

\author{
Eli Yuliansih $^{1}$, YasirArafat $^{2}$, Achmad Wahidy $^{3}$ \\ ${ }^{1} \mathrm{M}$ Madrasah Aliyah Negeri 1 MusiBanyuasin \\ ${ }^{2}$ Universitas PGRI palembang
}

\begin{tabular}{l} 
Article Info \\
\hline Article history: \\
Received Jul $12^{\text {th }}, 2021$ \\
Revised Aug $16^{\text {th }}, 2021$ \\
Accepted Aug $30^{\text {th }}, 2021$ \\
\hline
\end{tabular}

\section{Keyword:}

First keyword Second keyword Third keyword Fourth keyword Fifth keyword

\begin{abstract}
The purpose of this study was to determine the Effect of Learning Media and Learning Interests on Student Learning Outcomes in Man 1 MusiBanyuasin. Students of Man 1 Musi Banyuasin were the object of this study. The sample was conducted on 87 students of Man 1 MusiBanyuasin. The sampling technique used purposive sampling in which the respondents were some of the students of Man 1 Musi Banyuasin. The data collected by distributing questionnaires using a 5-point Likert scale to measure 73 statement items. The analysis technique used was multiple linear regression analysis. The results showed that first, students' interest in learning and the use of learning media simultaneously had a significant effect on student learning outcomes. Second, student learning interest had a partial and significant impact on student learning outcomes. Third, the use of learning media had a partial and significant impact on student learning outcomes.
\end{abstract}

(C) 2021 The Authors. Published by IICET.

This is an open access article under the CC BY-NC-SA license

(https://creativecommons.org/licenses/by-nc-sa/4.0

\section{Corresponding Author:}

Eli Yuliansih

MAN 1 MusiBanyuasin

Email: eliyuliacantik2020@gmail.com

\section{Introduction}

Every teaching activity is to achieve educational goals. Teaching is a process of learning and teaching activities, in which two subjects are mutually involved, namely the teacher as an educator and the student as a student. In the teaching process, elements of the learning process play a vital role. Teaching is the process of guiding student learning activities. Learning means a renewal towards individual development so that life can be better. Learning is a modification or reinforcing behavior through experience. [1]

The learning process is the core of the formal and informal education process, in which there is an interaction between the various learning components. These components are the teacher, content or subject matter, and students. The interaction among the three components includes facilities and infrastructure, learning methods, instructional media, learning models, and structuring the learning environment so that they can support the achievement of the planned learning process. Surachmad argues that "Teaching and learning activities need appropriate methods and have supporting tools in the teaching and learning process. The use of tools in the teaching and learning process aims to enhance learning achievement ". [2] So to increase students learning outcomes need support from learning tools or media.

Each learning process expects that students will get good learning outcomes. However, in reality, the learning outcomes obtained by students are not always as good as expected. As we rated that a good learning 
outcome is passing the KKM (standard minimum score) which has been determined as a benchmark for the success of the learning process. It should be a concern and evaluation material in the learning process.

Poor student learning outcomes are one of the problems in education. Student learning outcomes show the ability and quality of students as an impact of the learning process they have been through. Melton implies that learning outcomes are actions and performances that contain and reflect the competence of students who successfully use content, information, ideas, and tools in learning. Therefore learning outcomes can be defined as competencies and skills that students have after the learning period [3]

The results of preliminary studies indicate that student learning outcomes are not optimal. This is reflected in the student learning outcomes that have not reached the KKM standard. The question that arises from these problems is why student learning outcomes are not optimal? Referring to the perspective of learning theory, many factors affect student learning outcomes, both internally and externally. Internal factors include interest in learning which is thought to strongly affect student learning outcomes.,

As far as the author observed, there are still many teachers in every 9 years of basic education (SD and SMP) who still adhere to the old paradigm of the learning process. The old paradigm of teaching and learning in education is based on the theory, the tabula rasa assumption of John Loeke, who says that The child's mind is like a clean white blank paper and is ready to wait for the teacher's scribbles. Following this theory, a child's brain is like an empty bottle that can be filled with all the knowledge and wisdom of the teacher.

The importance of learning media has begun to be felt by teachers and students. One of the learning media is made in the form of videos which present information such as providing directions, assistance, instructions, and motivation in both sound and visual forms. The use of video-based learning media is one of the methods used by teachers to deliver material to students so that it is easy to understand the material.

Research by TjahyoSoebroto, et al (2009) states that learning with visual media in the classroom affects student interest and learning outcomes. [4] Interest as an internal factor has a role in supporting student learning outcomes. Students who are not interested in the learning material will show a less sympathetic, lazy, and not enthusiastic attitude in the teaching-learning process. Interest in a particular field will generate spontaneous attention to that field. Attention is an element of interest. Attention is very important in following activities well, and this will also affect students' interest in learning. [5] Interest is the choice of pleasure for each individual to do an activity. Interest is something that can arouse someone's passion and cause that person to use time, money, and energy for his liking for that object [6] Interest is a constant tendency to notice and reminisce about certain activities. Activities that are of interest to someone, continuous attention accompanied by pleasure, interest is a source of interest that encourages people to do what they want if they are free to choose. When they see that something will be profitable, they feel interested. It brings satisfaction. When satisfaction decreases, interest decreases [7]

Interest is an attitude or psychological condition characterized by focusing attention on certain problems or activities or as a tendency to understand an experience and will always be repeated. Interest can be related to the power of the movement that encourages us to tend or feel attracted to people, objects, activities, or it can be an effective experience stimulated by the activity itself. Interest is an attitude of interest or being fully involved in an activity because it realizes the importance and value of the activity. [8]

The phenomenon that occurs in MAN Negeri 1 Musi Banyuasin is that the test scores received by students are still not maximal because they are still below the specified KKM score. Besides, the level of student attendance is still not good. This can be seen from the high level of student absenteeism in schools which is caused by various things including the lack of interest in student learning. Another phenomenon is that the ability of subject teachers to use learning media is still not optimal, this can be seen from the use of instructional media, not all teachers use it so that students' ability to capture knowledge is not optimal

Based on the results of preliminary observations and previous studies, researchers are interested in researching the Effect of Learning Media and Learning Interest on Students Learning Outcomes.

Poor student learning outcomes are one of the problems in education. Student learning outcomes show the ability and quality of students as an impact of the learning process they have been through. Melton implies that learning outcomes are actions and performances that contain and reflect the competence of students who successfully use content, information, ideas, and tools in learning. Therefore learning outcomes can be defined as competencies and skills that students have after the learning period [3]

The results of preliminary studies indicate that student learning outcomes are not optimal. This is reflected in the student learning outcomes that have not reached the KKM standard. The question that arises from these problems is why student learning outcomes are not optimal? Referring to the perspective of learning theory, 
many factors affect student learning outcomes, both internally and externally. Internal factors include interest in learning which is thought to strongly affect student learning outcomes.,

As far as the author's observation, there are still many teachers in every 9 years of basic education (SD and SMP) who still adhere to the old paradigm of the learning process, the old paradigm of teaching and learning in education is based on the theory, the tabula rasa assumption of John Loeke, who says that The child's mind is like a clean white blank paper and is ready to wait for the teacher's scribbles. Following this theory, a child's brain is like an empty bottle each filled with all the knowledge and wisdom of the teacher.

The importance of learning media has begun to be felt by teachers and students. One of the learning media is made in the form of videos which present information such as providing directions, assistance, instructions, and motivation in both sound and visual forms. The use of video-based learning media is one of the methods used by teachers to deliver material to students so that it is easy to understand the material to be delivered.

\section{Method}

This study is quantitative research, that is, according to [18] is research that focuses on the study of objective phenomena to be studied quantitatively. Quantitative research is a process that uses data in the form of numbers as a tool to analyze information about what you want to know. This study uses a lot of numbers, ranging from data collection, interpretation of data, and displaying research results. The data used in this study are primary, namely questionnaire data obtained from interviews with teachers and students. This study consists of two independent variables, namely learning media (X1), learning interest (X2), while the dependent variable is learning outcomes $(\mathrm{Y})$.

The data was conducted quantitatively. This research method used partial and simultaneous regression methods. It is used for analysis or hypothesis testing if the researcher intends to know the effect or relationship of the independent variable with the dependent, where one of the independent variables is controlled (made permanent). According to [19], the ex post facto research design is research that aims to investigate events that occurred and then according to backwardness to find out the factors that caused these events.

The population in this study were all of the teachers in MAN 1 Musi Banyuasin in which consisted of 20 teachers. This sample was taken by the researcher using a saturated sampling technique, namely a sampling technique that took the entire number of populations (Sugiyono, 2012: 119)

In this study, data collected through questionnaires, interviews, observations, exams or tests, documentation, and so on. [20] Furthermore [21] states that data collection techniques can be done by interviewing, questionnaires, observations, and a combination of the three. In this study, the data collection techniques used by the researcher were a questionnaire that the respondent had to answer according to the situation he had experienced, observation, and documentation.

Data collected using a Likert scale model. The data analysis technique used simple regression analysis and multiple regression using SPSS For Windows version 25.00 data and displaying research results. The data used in this study are primary, namely questionnaire data obtained from interviews with teachers and students. This study consists of two independent variables, namely learning media (X1), learning interest (X2), while the dependent variable is learning outcomes (Y).

\section{Results and Discussions}

\section{The influence of learning media on learning outcomes}

The model of the relationship between learning media and learning outcomes is expressed in the form of the regression equation $\mathrm{Y}=63.977+0.324 \mathrm{X} 1$. The significance test of the regression equation can be presented in the following table.

Based on the significance test of the learning media variable on the results in MAN 1 MusiBanyuasin, the $t$ value $(5.291)>$ the $t$ table (1.9876), where the $t$ value is greater than the table, and the significance value of 0.000 is less than 0.05 , so Hol is accepted so that there is a significant influence between learning media on student learning outcomes at MAN 1 MusiBanyuasin 


\section{Influence of interest in learning on teacher learning outcomes}

The model of the relationship between learning media and learning outcomes is expressed in the form of the regression equation $\mathrm{Y}=63.977+0.324 \mathrm{X} 1$. The significance test of the regression equation can be presented in the following table.

Based on the significance test of the learning interest variable on student learning outcomes in MAN 1 Musi Banyuasin, the $t$ value is (11.864) $>$ the $t$ table price (1.9876) where the $t$ value is greater than the $t$ table, and the significance value is 0.000 less than 0.05 , so Hol accepted so that there is a significant influence between interest in learning on student learning outcomes at MAN 1 MusiBanyuasin

\section{The influence of learning media and learning interest on student learning outcomes}

The relationship model of learning media and learning interest towards learning outcomes is expressed in the form of the regression equation $\mathrm{Y}=16,142+0.869 \mathrm{X} 1-0.044$. It means that learning outcomes will increase positively with learning media and negatively on learning interest

To find out the truth of hypothesis testing, a simultaneous test was carried out using the $\mathrm{F}$ test to determine the effect of learning media variables and learning interest on student learning outcomes. The test criteria are as follows

a. If the probability value (significant) $<0.005$, then Ho3 is rejected

b. b. If the probability value (significant) $>0.005$, then Ho3 is accepted

Then for the $\mathrm{F}$ test, the test criteria are as follows

a. Ha3 is accepted if Fcount $>$ Ftable

b. H03 is accepted if Fcount $\leq$ Ftable.

The results of multiple regression analysis can be seen in the following table. 4. The results of multiple regression analysis of learning media and interest in learning on learning outcomes

Based on the significance test of the learning media variables and the interest in learning together on the learning outcomes of teachers at MAN 1 MusiBanyuasin, the $\mathrm{f}$ value is $70.069>$ the $\mathrm{f}$ table price is 3.10 where the calculated $\mathrm{f}$ value is greater than the $\mathrm{f}$ table and the significance value is 0.001 which smaller than 0.005 then $\mathrm{Ho} 3$ is accepted so that there is a significant influence between learning media and interest in learning together on student learning outcomes at MAN 1 Musi Banyuasin

To find out how much influence the independent variable has on the dependent variable, it can be seen simultaneously in the following summary model table

The table above shows the R-value which is a symbol of the correlation coefficient value. At the value above, the correlation value is 0.791 . This value shows that the relationship between the two research variables is in the strong category. From table also obtained the value of R Square or the coefficient of determination (KD) which shows how good the regression model is formed by the interaction of the independent and dependent variables. The value of KD obtained is 0.625 which can be interpreted that the independent variable $\mathrm{X}$ has a contribution effect of $57.7 \%$ on variable $\mathrm{Y}$ and 37.5 , the other\% is influenced by other factors outside variable $\mathrm{X}$

\section{Efforts to improve learning outcomes through increasing learning media}

Based on the results of observations at school, it appears that there are a lot of tools or tools used by teachers to carry out the learning process. Several tools or media used are projectors, laptop, internet network, some animation and video, and other props.

Also, there are several props in the form of tools in the form of a globe, atlas, calculating machine, and so on. Based on the results of the interviews, most students felt that the media or learning tools at school made it easier for them to understand the subject matter at school. By looking at the videos and animations that are displayed in the projector, students feel that they see a real picture that is the real result or material seen in the real world.

Through learning media, students feel that the material is easier to understand, this can be seen from the interview answers that most of them strongly agree with the use of learning media because they are more enthusiastic about learning and learning outcomes are getting better.

Media is anything that can be used to convey messages, stimulate students' thoughts, feelings, attention, and willingness so that they can be encouraged to be involved in the learning process. [10] 
Learning media can be used to help students improve learning outcomes because learning media can stimulate students' thoughts, feelings, attention, and willingness. Learning media are currently being used in advanced schools in urban areas. It is proper that MAN 1 Musi Banyuasin should use learning media to improve overall student learning outcomes.

This research is in line with research [22] entitled The Effect of Learning Media on the Arabic Language Learning Motivation of Students at Madrasah Tsanawiyah. Increasing student motivation or interest in learning can be reached by using learning media. The results of this study inform that there is a significant influence between learning media on student learning motivation, especially in learning Arabic.

This research is in line with Wahidy's 2019 research with the title Creative Education Learning Innovation (Efforts to Improve Learning Outcomes through the Application of Learning Models) M. Research results in the target is not only students but also teachers whose creative potential is explored. Because in fact, a creative teacher who plays a role in improving the quality of his education has a significant impact, one of which is by honing his hidden creative potential in the teacher. So that all elements of education have a high dedication to the development of the quality and quality of education that is expected [23]

The research by Soebroto, et al with the title The Effect of Visual Media in the Classroom on Student Interest and Learning Outcomes. In learning, a person must be able to interact with the environment. For this reason, the classroom must be designed to create an interactive situation for conducive learning. One way to make classrooms interactive is by installing visual media on the walls of the classroom. The purpose of this study was to determine the effect of visual media in the classroom and how much influence it has on students' interest and learning outcomes in chemistry [4]

\section{Efforts to improve learning outcomes through increased interest in learning}

The results of interviews and observation data obtained when collecting data show that students already have a high enough interest in learning. It can be seen from the attendance data which indicates that students have a high interest in learning. Besides, from the answer of asked questions about interest in the study, almost all of the answers strongly agree that learning at school is important and students are happy and excited to come to school to receive lessons from school

Students are excited to come to school because they think learning is important for the future, learning is fun, studying at school pleasures meeting friends, and having fun. They are proud to go to school, students are happy to pay attention to the lessons at school.

Interest is a constant tendency to notice and reminisce about certain activities. Activities that are of interest to someone, continuous attention accompanied by pleasure. Interest is a source of interest that encourages people to do what they want if they are free to choose. When they see that something will be profitable, they feel interested. It brings satisfaction. When satisfaction decreases, interest decreases [7]

So by increasing student interest in learning is expected to improve student learning outcomes at school. There are many ways that teachers can do to increase interest in learning.

This research is in line with Rusmiati's research entitled The Influence of Learning Interest on Learning Achievement in the Economic Studies of Ma Al Fattah Sumbermulyo Students. Based on the results of the study, the influence of interest in learning on learning achievement in the economic study of students at Madrasah Aliyah Al Fattah Sumbermulyo is high. [24]

From research by Nurhasanah, Siti, and Sobandi. A (2016: 128) with the title Learning Interest as a Determinant of Student Learning Outcomes, it can be concluded that student learning outcomes can be improved through increasing student interest in learning. This means that better student interest in learning will have an impact on student learning outcomes that are getting better. [25]

Research by Pangestu, et al. (2015.; 17-26) The Influence of Interest on Mathematics Learning Outcomes of Students of SMA Negeri 1 Uluiwoi, East Kolaka Regency, Journal of Mathematics Education Research. This research is an ex post facto study that aims to examine the effect of student interest in learning outcomes in mathematics at SMA Negeri 1 Uluiwoi. Based on the results of the data analysis, it is concluded that students' interest in learning has a positive influence on mathematics learning outcomes of students at SMA Negeri 1 Uluiwoi. [26]

\section{Efforts to improve learning outcomes through increasing learning media and interest in learning}

Teachers must be able to act not only as teachers but also as educators, mentors, coaches, and directors for their students. Students' strong interest in learning is believed to encourage students to strive and never give up 
in facing all challenges and obstacles in learning which will ultimately result in achievement in the form of optimal learning outcomes.

One of the ways to increase interest in learning is using learning media. There are many kinds of media of learning. Starting from audio media, video media, animation media, and various kinds of media that can be used. Especially now that the internet and cellphones are increasingly mushrooming, the internet and computers are very likely to be used as learning media tools for students.

The learning media used by the teacher in the learning process carried out must be able to support the achievement of predetermined competencies. Factors that must be considered in selecting the media include the suitability of the material, effectiveness, and conformity with the applicable education system. The use of media in theoretical learning will certainly be different from the media used in practical learning. Therefore, a teacher must be able to choose or make appropriate learning media for students. Learning media can be in the form of props, simulation tools, pictures, animation, audio, and other media.

his research is in line with AchmadWahidy's research. Based on the results of the analysis of the research data, it can be concluded that the results of observations during the learning process of reading comprehension using the talking stick learning model, show that the reading process of students' understanding is very active. The results of the truth testing of the hypothesis that the author proposes to show that tcount $>$ ttable, namely 3.37> 1.67, this means that there is an effect of the talking stick learning model on the reading comprehension ability of grade VIII students at SMP PGRI Sukamoro, Banyuasin Regency, the truth is proven and acceptable [27]

This research is in line with the research of Supardi et al (2017; 71-78) with the title The Effect of Learning Media and Learning Interest on Physics Learning Outcomes. The purpose of this study was to obtain a suitable physics learning media that can help in understanding the basic concepts in learning physics, especially for the completion of straight motion material in class VII SMP. The results of the study there is an effect of the interaction of learning media and interest in learning on learning outcomes in physics [28]

This is related to Fatiah's research. This research was conducted at SMA Negeri 5 Surakarta in 2013. This research is a quantitative research using comparative causal methods or ex post facto research. Based on data analysis and discussion, it can be concluded that (1) There is a positive influence of learning media on learning outcomes at SMA N 5 Surakarta. (2) There is a positive effect of teacher work motivation on learning outcomes at SMA N 5 Surakarta. (3) There is a positive effect of learning media and teacher work motivation on learning outcomes at SMA N 5 Surakarta. [29]

This research is in line with and related to the research of Fenti et al., The Influence of Learning Media and Work Motivation on Learning Outcomes. The results showed (1) that learning media and work motivation had a positive effect on learning outcomes, (2) learning media had a positive effect on learning outcomes, (3) work motivation had a positive effect on learning outcomes [30]

\section{Conclusions}

Based on the results of data analysis that the effect of interest in learning and learning media both partially and simultaneously on teacher work performance can be explained as follows ; a)Based on the previous test results, it can be seen that the learning interest variable has a greater $t$-count than the $t$ table. . This shows that students' interest in learning has a partial and significant effect on student learning outcomes. This means that the initial hypothesis is rejected and the second hypothesis is accepted. b) Based on the results of previous tests, it can be seen that the learning media variable has a greater $t$-count than the $t$ table. This shows that student learning media has a partial and significant effect on student learning outcomes so this means that the initial hypothesis is rejected and the second hypothesis is accepted. c) Based on the results of previous tests, it can be seen that the variable interest in learning and learning media has a value of f-count is greater than $\mathrm{f}$ table. This shows that interest in learning and student learning media have a simultaneous and significant effect on student learning outcomes. 


\section{References}

O. Hamalik, Kurikulum dan Pembelajaran. Jakarta.: Bumi Aksara, 2011.

W. Surachmad, Pengantar Interaksi Mengajar -Belajar Dasar dan Tekhnik Metodologi Pengajaran. Bandung: Tarsito, 2003.

B. Molstad, C. E., \& Karseth, "National Curricula in Norway and Finland: The Role of Learning Outcomes.," Eur. Educ. Res. J., vol. 15, no. 3, pp. 329-344, 2016.

Soebroto, Tjahyo. Sigit Priatmoko, Nurma Siyamita., "Pengaruh Media Visual Di Ruang Kelas Terhadap Minat Dan Hasil Belajar Kimia Siswa," J. Inov. Pendidik. Kim., vol. 3, no. 1, pp. 400-405, 2019.

J. . L. Loekmono, .Belajar Bagaimana Belajar. Salatiga: BP Gunung Mulya, 1994.

Maonde, Faad., "Pengaruh Kovariat Minat dan Pengetahuan Dasar Siswa terhadap Hasil Belajar Matematika," J. Pendidik. Mat., vol. 1, no. 1, 2010.

Slameto, Belajar dan Faktor-faktor yang Mempengaruhi,. Jakarta.: Rineka Cipta, 2003.

J. Sudarsono, Tentang Sistem Pendidikan Nasional. Jakarta.: Rineka Cipta, 2003.

Arsyad, Media Pembelajaran. Jakarta.: Raja Grafindo Persada, 2011.

Angkowo R. dan A. Kosasih, Optimalisasi Media Pembelajaran. Jakarta.: Grasindo, 2007.

Daryanto., Pengelolaan Budaya Dan Iklim Sekolah. Yogyakarta: Gava Media, 2015.

W. S. Wikel, Psikologi Pengajaran. Yogyakarta: media Abadi, 1999.

A. Ahmadi, Psikologi Sosial. Jakarta.: Rineka Cipta, 2009.

N. Khodijah, Psikologi Pendidikan. Jakarta.: Raja Grafindo Persada, 2014.

Syah. Muhibbin, Psikologi Belajar. Jakarta.: Raja Grafindo Persada, 2003.

N. Purwanto, Evaluasi hasil belajar. Yogyakarta: Pusaka Pelajar., 2014.

Sudjana , Ahmad Rivai, Dasar-dasar Proses Belajar Mengajar. Bandung: Sinar Baru Algesindo., 2005.

H. M. Musfiqon, Metodologi Penelitian Pendidikan. Jakarta.: PT Prestasi Pustakaraya, 2012.

Sugiyono, Metode Penelitian Kuantitatif dan R dan D. Bandung: Alfabeta, 2013.

Arikunto, . Prosedur Penelitian Suatu Pendekatan Praktek. Jakarta.: Rineka Cipta, 2010.

Sugiyono., Metode Penelitian Pendidikan: Pendekatan Kuantitatif, Kualitatif, dan R\&D. Bandung: Alfabeta, 2012.

Putri, Wakhidati, "Pengaruh Media Pembelajaran Terhadap Motivasi Belajar Bahasa Arab Siswa Madrasah Tsanawiyah," . Lisania J. Arab. Educ. Lit., vol. 1, no. 1, pp. 1-16, 2017.

D. Effendi and A. Wahidy, "Prosiding seminar nasional pendidikan program pascasarjana universitas PGRI palembang," Pemanfaat. Teknol. Dalam Proses Pembelajaran Menuju Pembelajaran Abad 21, vol. 2, pp. 999$1015,2019$.

Rusmiati, "Pengaruh Minat Belajar Terhadap Prestasi Belajar Bidang Studi Ekonomi Siswa Ma Al Fattah Sumbermulyo," . Util. J. Ilm. Pendidik. dan Ekon. Vol., vol. 1, no. 1, pp. 21-36, 2017.

Nurhasanah , Siti dan A. Sobandi., "Minat Belajar Sebagai Determinan Hasil Belajar Siswa," J. Pendidik. Manaj. Perkantoran, vol. 1, no. 1, pp. 128-135, 2016.

K. T. Pangestu, Agung Dwi. Hafiludin Samparadja, "Pengaruh Minat Terhadap Hasil Belajar Matematika Siswa Sma Negeri 1 Uluiwoi Kabupaten Kolaka Timur," J. Penelit. Pendidik. Mat., vol. 3, no. 2, pp. 17-26, 2013.

A. Wahidy, "Pengaruh Model Pembelajaran Talking Stick Terhadap Kemampuan Membaca Pemahaman Siswa Kelas Viii Smp Pgri Sukamoro Kabupaten Banyuasin Oleh," Kumpul. J. Dosen PGRI, vol. 6, no. 1, pp. 72-86, 2017.

R. Supardi U.S. Leonard, Huri Suhendri, "Pengaruh Media Pembelajaran Dan Minat Belajar Terhadap Hasil Belajar Fisika," J. Form., vol. 2, no. 1, pp. 71-81, 2017.

Fatiah, "Pengaruh Sertifikasi Guru Dan Motivasi Kerja Guru Terhadap Kinerja Guru SMAN 5 Surakarta," Jupe UNS, vol. 2, no. 1, 2018.

Fenty, Edi Harapan, Destiniar, "Pengaruh Sertifikasi Guru Dan Motivasi Kerja Terhadap Kinerja Guru," J. Manajemen, Kepemimpinan, dan Supervisi Pendidik., vol. 6, no. 1, 2021. 